\title{
Redesain Pasar Cepogo dengan Pendekatan Arsitektur KONTEKSTUAL DI BOYOLALI
}

\author{
Angela Ayu Desmaria, Hari Yuliarso, Tri Yuni Iswati \\ Program Studi Arsitektur \\ Fakultas Teknik \\ Universitas Sebelas Maret Surakarta \\ Email : aadesmaria@yahoo.com
}

\begin{abstract}
Pasar Cepogo is a public commercial centre in Cepogo. This traditional market is the preferred place to shop daily needs by the residents of Cepogo and people living in its surrounding area since it offers array of affordable prices. There are social aspects of the tradition manifested in the way bargains are settled. Yet, this market still has problems such as inconvenient environment, cluttered floor plan, uncharted activities, and decaying infrastructures. Based on these conditions, the design problem consists of creating a space to cater all activities in Pasar Cepogo and taking form fitting to its surrounding in order to maintain its existence as a traditional market. Redesign project of Pasar Cepogo aims to improve the condition of the market in order to provide convenient commercial space suiting present-day demand without leaving its traditional roots. Hence, contextual architecture approach is considered fit the notion. Contextual theme aspires to appropriate the redesigned building for its site, which concerns physical features, climate, culture, and local architecture aspects of the surrounding area. Physical features approach influence the site management adapted to the site conditions. Climate aspects approach is implemented into design response to the local climate, such as the use of a high and sloping roof, tritisan, and cross ventilation. The cultural approach is actualized into the space management adapted to the context of activities in Pasar Cepogo. Local architecture approach is implemented into the form and appearance of the building, adjusting Java architecture and Hindu architecture that once evolved in Cepogo.
\end{abstract}

Keywords: Contextual Architecture, Market Redesign, Traditional Market.

\section{PENDAHULUAN}

Pasar Cepogo merupakan pasar tradisional yang berada di Kecamatan Cepogo, Kabupaten Boyolali. Pasar ini berlokasi di Jalan Boyolali-Magelang yang merupakan jalur wisata Solo-Selo-Borobudur (SSB). Pasar Cepogo memiliki peran strategis sebagai pusat perekonomian masyarakat Cepogo dan sekitarnya. Pasar Cepogo ini juga menjadi ruang publik dimana masyarakat sekitarnya berkumpul dan membangun relasi sosial di sini. Selain itu, Pasar Cepogo merupakan salah satu wujud budaya lokal yang perlu dilestarikan nilai-nilai budayanya.

Pasar Cepogo yang dimaksud di sini adalah Pasar Cepogo pasca kegiatan grosir sayuran dipindahkan ke Pasar Sayuran Cepogo. Walaupun pembangunan Pasar Sayuran Cepogo ini cukup mengurangi kepadatan pasar, namun masih ditemui banyak permasalahan. Adanya kegiatan yang belum terwadahi seperti parkir dan bongkar muat mengakibatkan terganggunya kegiatan di sekitar pasar. Penataan yang kurang rapi dan sistem utilitas yang belum memadahi juga mengurangi kenyamanan di dalam pasar. Selain itu, bangunan pasar ini juga sudah tua dan mulai rusak sehingga banyak fasilitas dagang yang ditinggalkan oleh pemiliknya. Oleh karena itu, diperlukan perencanaan dan perancangan kembali Pasar Cepogo sebagai pasar tradisional yang dapat mewadahi seluruh kegiatan di dalamnya dengan nyaman dan teratur. Redesain Pasar Cepogo ini merujuk pada upaya untuk memperbaiki Pasar Cepogo secara fisik dan tetap mempertahankan eksistensinya sebagai pasar tradisional, sehingga dalam mewujudkan hal tersebut perlu memperhatikan agar kekhasan dan budaya pada Pasar Cepogo tetap terjaga. Tingkat perubahan yang dilakukan pada redesain ini adalah secara total atau dapat disebut dengan 
pembangunan kembali (redevelopment) dengan mempertahankan lokasi, fungsi serta nilai budaya.

Adanya tuntutan untuk menjaga kekhasan pasar tradisional dan Peraturan Daerah Kabupaten Boyolali tentang Pengelolaan dan Pemberdayaan Pasar Tradisional yang telah mengatur bahwa bentuk bangunan pasar harus selaras dengan karakteristik budaya daerah, maka metode desain yang akan digunakan pada redesain Pasar Cepogo ini adalah Arsitektur Kontekstual. Arsitektur Kontekstual bertujuan untuk melestarikan unsur-unsur lokal pada karya yang baru tanpa mengesampingkan budaya dan lingkungan setempat.

\section{METODE}

Metode yang digunakan dalam Redesain Pasar Cepogo Boyolali ini menggunakan pendekatan Arsitektur Kontekstual. Kontekstual berarti memperhatikan dan menghormati lingkungan fisik sekitarnya, mengutamakan kesinambungan visual antara bangunan baru dengan bangunan landmark dan gaya setempat yang telah diakui sebelumnya (Brolin, 1980). Kontekstual adalah metode desain yang mempertimbangkan dan memberikan tanggapan terhadap berbagai karakter di sekitarnya (lingkungannya). Tanggapan terhadap konteks lingkungan meliputi struktur fisik lingkungan, iklim, budaya, dan gaya arsitektur lokal (Widati, 2015). Keempat faktor tersebut akan menjadi pendekatan dalam penerapan prinsip kontekstual.

1. Pendekatan Fisik Lingkungan

Pendekatan kontekstual terhadap fisik lingkungan berupaya menyesuaikan desain dengan kondisi tapak yang sudah ada. Pendekatan ini akan digunakan pada pengolahan tapak dan pemilihan material.

2. Pendekatan terhadap Iklim

Pendekatan terhadap iklim ini bertujuan untuk memanfaatkan potensi dan kondisi alam untuk menunjang kenyamanan ruang. Pendekatan ini akan diterapkan pada analisis tapak terhadap iklim.

3. Pendekatan Budaya
Kontekstual tidak hanya mengarah pada aspek visual, namun terkait juga dengan aspek non fisik berupa sejarah, sosial, dan budaya yang melatarbelakangi terwujudnya bangunan sebelumnya. Pendekatan budaya ini digunakan untuk menganalisa kegiatan di dalam pasar. Berbagai budaya khas Pasar Cepogo akan nampak pada seluruh kegiatan di dalamnya. Hasil dari identifikasi kegiatan ini akan digunakan untuk menentukan kebutuhan ruang. Dengan demikian, budaya khas dalam Pasar Cepogo akan terwadahi dan tercipta nuansa khas pasar tradisional.

4. Pendekatan Gaya Arsitektur Lokal

Pendekatan terhadap gaya arsitektur lokal ini akan berpengaruh terhadap bentuk dan tampilan bangunan yang dirancang, pemilihan material serta struktur. Untuk memperoleh keselarasan dengan bangunan yang sudah ada sebelumnya dapat dicapai melalui dua aspek, yaitu aspek visual umum dan aspek sejarah. Aspek visual umum dilakukan dengan menerapkan gaya arsitektur setempat, yaitu Arsitektur Jawa. Aspek sejarah dilakukan dengan memperhatikan bangunan bersejarah yang pernah berkembang di Cepogo, yaitu Arsitektur Hindu pada bangunan candi yang ditemukan di Cepogo.

\section{ANALISIS}

Berikut ini merupakan analisis untuk menentukan konsep perencanaan dan perancangan sebagai arahan dalam proses desain.

\subsection{Analisis Ruang}

Analisis kebutuhan ruang diperoleh dengan melakukan identifikasi pelaku dan kegiatan pelaku pada kondisi eksisting. Perencanaan peruangan ini disesuaikan dengan karakter khas pada eksisting Pasar Cepogo, sehingga seluruh kegiatan tersebut dapat terwadahi dengan kapasitas yang lebih memadahi tanpa menghilangkan kekhasan budaya pada Pasar Cepogo. Berdasarkan hasil identifikasi pelaku dan pola kegiatannya maka kegiatan yang akan diwadahi dapat dikelompokkan menjadi beberapa kelompok kegiatan. Secara garis besar, ruang yang 
dibutuhkan harus mampu mewadahi tiga kegiatan utama, yaitu kegiatan jual beli pasar tradisional (lihat Gambar 1), kegiatan pada pasar hewan (lihat Gambar 2), dan kegiatan wisata dalam bentuk rekreasi suasana khas pasar tradisional, kuliner, dan wisata belanja produk khas (lihat Gambar 3 dan 4). Selain itu, diperlukan pula wadah bagi kegiatan pengelola, servis, dan fasilitas umum lainnya yang menunjang seluruh kegiatan di dalam pasar (lihat Tabel 1).

Tabel 1. Kebutuhan Ruang

\begin{tabular}{|c|c|}
\hline $\begin{array}{l}\text { Kelompok } \\
\text { kegiatan }\end{array}$ & Kebutuhan ruang \\
\hline $\begin{array}{l}\text { Kelompok } \\
\text { kegiatan } \\
\text { penerimaan }\end{array}$ & Hall penerimaan \\
\hline $\begin{array}{l}\text { Kelompok } \\
\text { kegiatan jual } \\
\text { beli pasar } \\
\text { tradisional }\end{array}$ & $\begin{array}{l}\text { Kios } \\
\text { Los } \\
\text { Oprokan/pelataran }\end{array}$ \\
\hline $\begin{array}{l}\text { Kelompok } \\
\text { kegiatan jual } \\
\text { beli pasar hewan }\end{array}$ & $\begin{array}{l}\text { Tempat ternak kambing } \\
\text { Tempat ternak ayam } \\
\text { Tempat ternak bebek } \\
\text { Penampungan kotoran } \\
\text { hewan }\end{array}$ \\
\hline $\begin{array}{l}\text { Kelompok } \\
\text { kegiatan wisata }\end{array}$ & $\begin{array}{l}\text { Kios/los barang } \\
\text { kerajinan } \\
\text { Area kuliner } \\
\text { Area santai }\end{array}$ \\
\hline $\begin{array}{l}\text { Kelompok } \\
\text { kegiatan } \\
\text { pengelola }\end{array}$ & $\begin{array}{l}\text { Ruang kerja } \\
\text { Ruang tamu } \\
\text { Ruang arsip } \\
\text { Ruang rapat } \\
\text { Ruang pemantauan } \\
\text { CCTV } \\
\text { Pantry }\end{array}$ \\
\hline $\begin{array}{l}\text { Kelompok } \\
\text { kegiatan } \\
\text { penunjang }\end{array}$ & $\begin{array}{l}\text { Area parkir } \\
\text { Pos jaga } \\
\text { Ruang penyimpanan alat } \\
\text { kebersihan } \\
\text { Ruang MEE } \\
\text { Toilet } \\
\text { Mushola } \\
\text { Gudang } \\
\text { Area bongkar muat }\end{array}$ \\
\hline
\end{tabular}
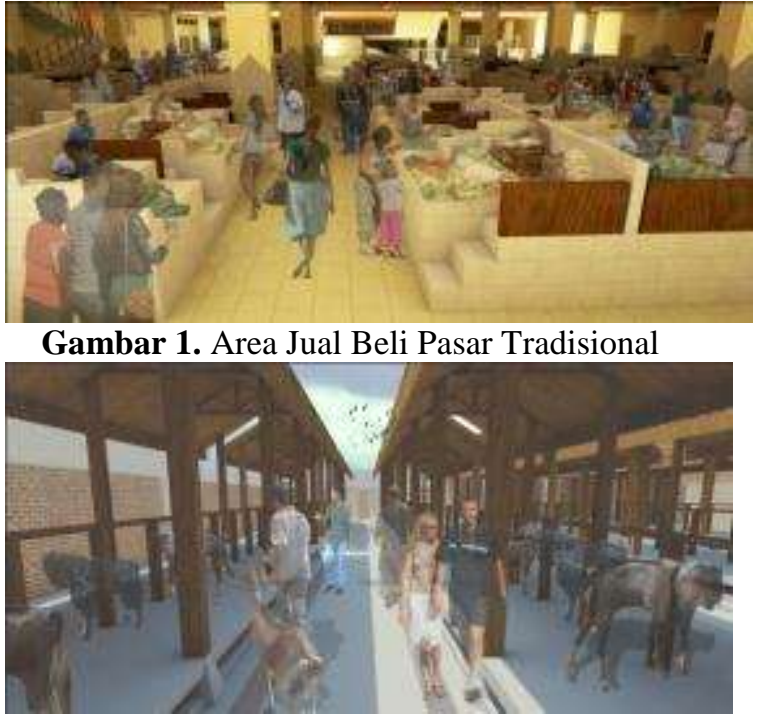

Gambar 2. Area Jual Beli Pasar Hewan

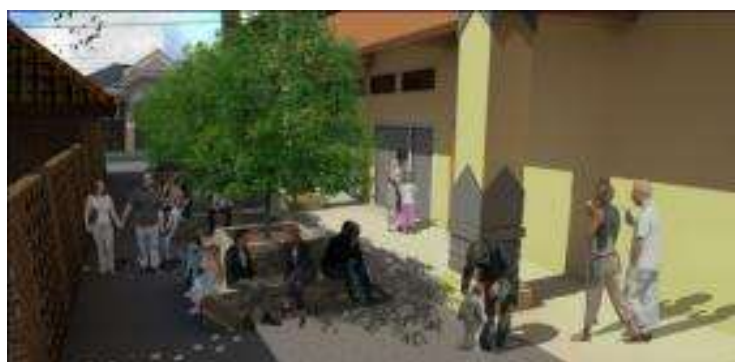

Gambar 3. Area Santai

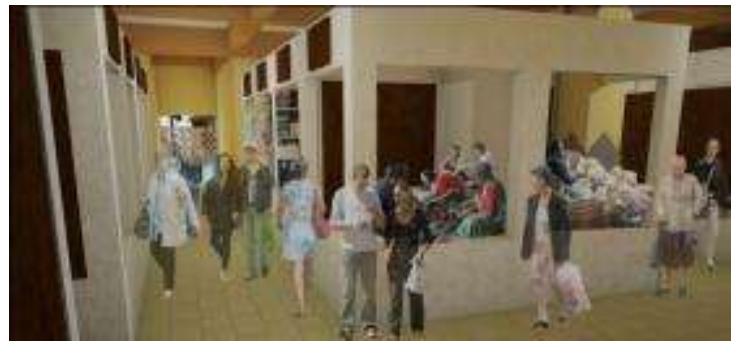

Gambar 4. Area Dagang Barang Kerajinan

\subsection{Analisis Pengolahan Tapak}

Analisis pengolahan tapak terdiri atas analisis pencapaian, analisis klimatologis, dan analisis pemintakatan.

\subsubsection{Analisis Pencapaian}

Kriteria pola pencapaian menuju tapak antara lain adalah kemudahan akses, keamanan, kenyamanan, strategis, dan tidak mengganggu kegiatan yang lain. Penentuan pencapaian ini dilakukan dengan menganalisa kondisi eksisting di sekitar tapak dan arus kedatangan pengunjung, baik dengan kendaraan pribadi, kendaraan umum, kendaraan bongkar muat, kendaraan servis, dan pejalan kaki. Pencapaian pengguna ke 
dalam tapak perlu dibedakan agar kegiatan tersebut tidak saling mengganggu satu sama lain sehingga tercapai kenyamanan dan keamanan dalam aksesibilitas (lihat Gambar $5)$.

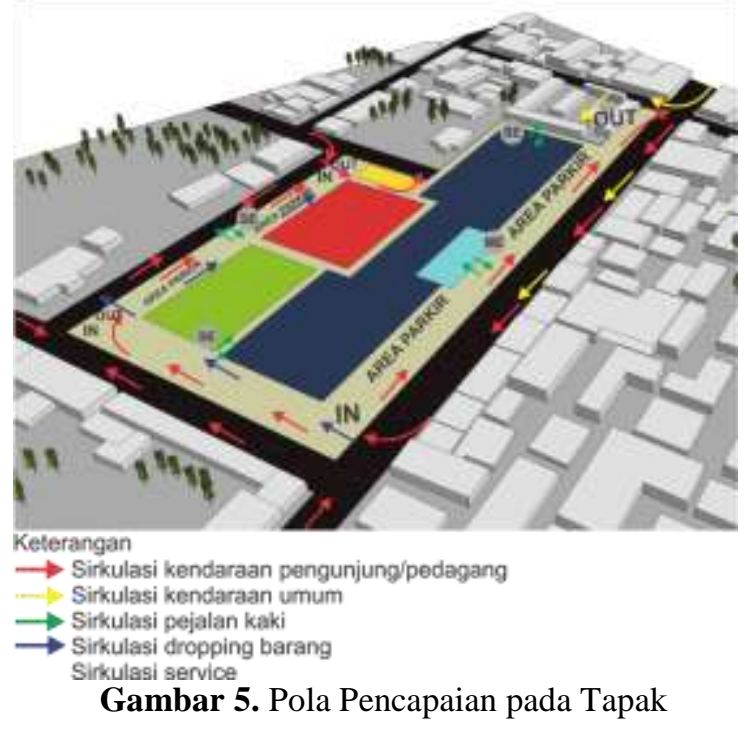

\subsubsection{Analisis Klimatologis}

Analisis klimatologis dilakukan sebagai bentuk penerapan kontekstual terhadap iklim. Kondisi iklim setempat akan dimanfaatkan untuk menunjang kenyamanan ruang. Berdasarkan hasil analisis dapat ditentukan respon desain terhadap iklim, khususnya matahari, angin, dan hujan.

1. Penggunaan elemen sun shading berupa tritisan pada sisi bangunan yang menerima sinar matahari secara langsung (lihat Gambar 6).

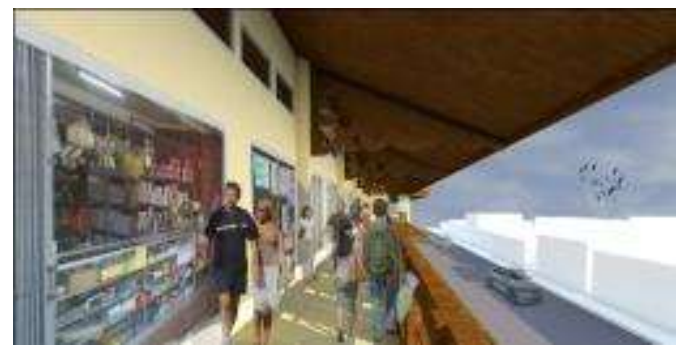

Gambar 6. Tritisan Bangunan sebagai

Pembayangan terhadap Sinar Matahari

2. Penggunaan vegetasi sebagai barrier untuk meminimalisir efek panas yang diterima oleh bangunan.

3. Penggunaan bentuk atap tinggi dapat mereduksi panas matahari yang diterima langsung oleh atap bangunan sehingga panas tidak merambat turun dan mempengaruhi ruang di bawahnya.

4. Menggunakan bukaan dengan sistem cross ventilation untuk memanfaatkan angin sebagai penghawaan alami (lihat Gambar 7).

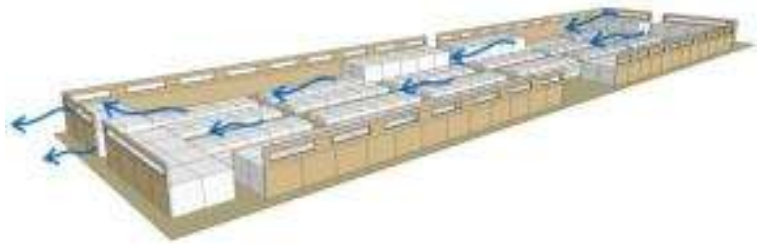

Gambar 7. Cross Ventilation

5. Penggunaan buffer udara kotor berupa vegetasi di sisi terluar tapak.

6. Penggunaan atap miring dan tritisan yang lebar untuk melindungi dari tampias hujan (lihat Gambar 6).

\subsubsection{Analisis Pemintakatan}

Analisis pemintakatan ini merupakan kesimpulan dari analisis yang dilakukan sebelumnya. Analisis ini didasarkan pada konteks lingkungan tapak dan organisasi ruang (lihat Gambar 8).

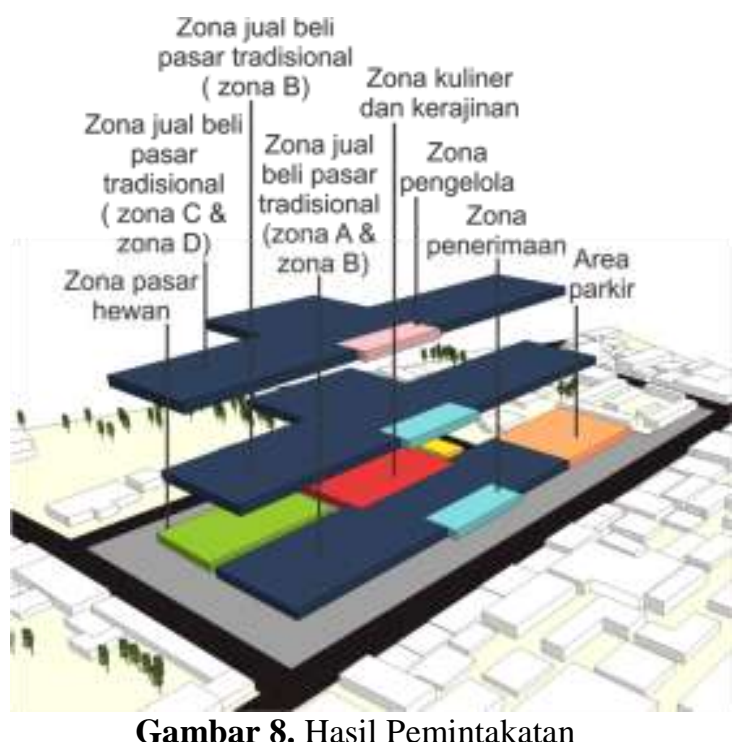

\subsection{Analisis Bentuk dan Tampilan Bangunan}

Bentuk dasar massa menyesuaikan bentuk denah bangunan sekitar yang banyak menggunakan langgam Arsitektur Jawa, yaitu bentuk dasar segi empat. Bentuk ini juga didasarkan pada penyesuaian dengan bentuk tapak karena keterbatasan luasan 
tapak, sehingga pemanfaatan tapak lebih optimal.

Penataan massa menggunakan pola majemuk yang dibagi menjadi beberapa massa, yaitu massa utama, massa pelengkap, dan massa penunjang. Massa utama merupakan massa yang mewadahi kegiatan utama yaitu jual beli pasar tradisional. Massa pelengkap merupakan massa pasar hewan yang harus dipisahkan dengan massa lain. Massa penunjang adalah massa yang mewadahi kegiatan penunjang atau servis pada tapak.

Proses transformasi massa menerapkan prinsip Arsitektur Hindu. Prinsip yang diterapkan adalah punden berundak dan tata letak candi dengan sistem berurutan sehingga tampak bangunan terlihat berundak menyerupai candi dengan massa bagian tengah merupakan massa yang lebih tinggi dibanding yang lain (lihat Gambar 9) .

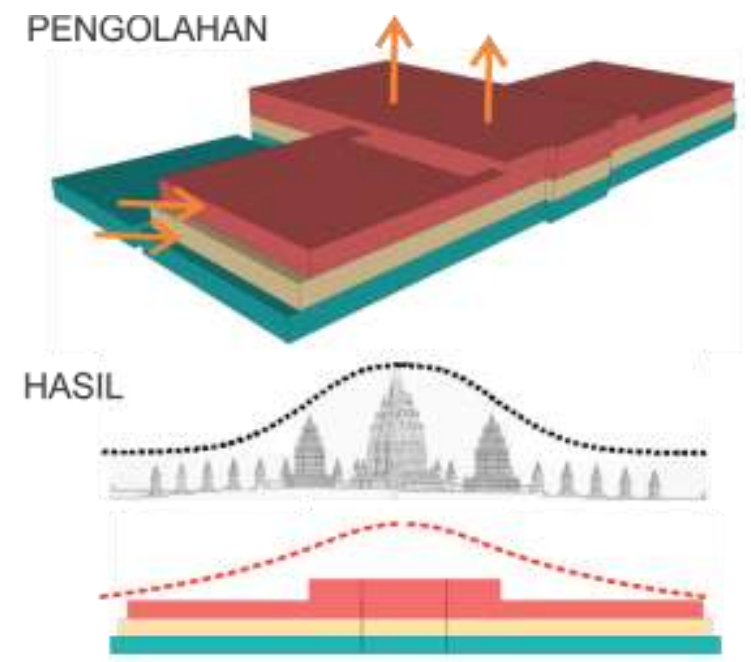

Gambar 9. Hasil Transformasi Massa

Perencanaan tampilan bangunan juga menyesuaikan dengan langgam Arsitektur Jawa. Ciri khas Arsitektur Jawa terletak pada bentuk atapnya, sehingga pada Pasar Cepogo ini akan diterapkan bentuk atap tradisional Jawa (lihat Gambar 10). Jenis atap yang digunakan adalah atap joglo, limasan, dan kampung. Tidak hanya atap, elemen Arsitektur Jawa yang lain juga diterapkan pada bangunan pasar, seperti konsol, kolom dan umpak, serta ornamen. Hal ini merupakan penerapan aspek visual umum sedangkan untuk penerapan aspek sejarah, tampilan pasar dipadukan dengan elemen candi pada desain tampilan bangunan. Selain itu, digunakan pula material candi pada pengolahan tampilan bangunan, yaitu batu alam (lihat Gambar 11).

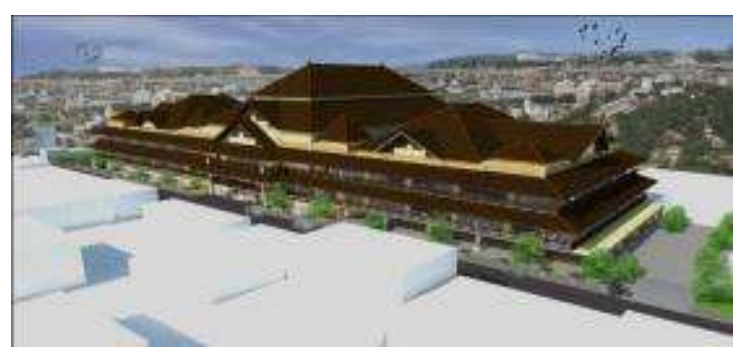

Gambar 10. Penerapan Arsitektur Jawa pada Bangunan

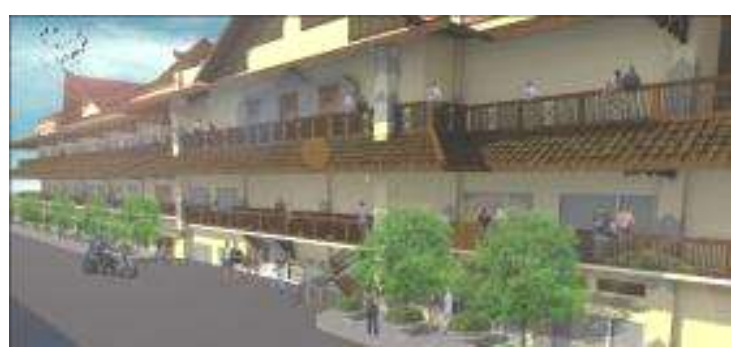

Gambar 11. Penerapan Elemen dan Material Candi pada Bangunan

\subsection{Analisis Struktur dan Pemilihan Material}

Sistem struktur pada bangunan akan dibagi menjadi tiga bagian menyesuaikan komponen struktur pada bangunan tradisional Jawa, yaitu sub structure (pondasi/bebatur), upper structure (kolom dan balok/cagak), dan super structure (rangka atap/empyak).

\section{Sub Structure}

Sesuai dengan konteks Arsitektur Jawa, pondasi umpak tetap diterapkan sebagai citra Arsitektur Jawa. Namun untuk menopang bangunan ini, pondasi umpak perlu didukung dengan pondasi yang lain, yaitu pondasi tapak (footplate) dan pondasi batu kali.

2. Upper Structure

Prinsip struktur rangka pada Arsitektur Jawa akan diterapkan pada Pasar Cepogo. Sistem struktur rangka ini terdiri dari kolom dan balok yang kemudian dilengkapi dengan sistem lantai dan dinding untuk pembentukan ruang.

3. Super Structure

Struktur rangka atap harus mampu menopang bentuk-bentuk atap Jawa yang diterapkan pada Pasar Cepogo. Pada 
bangunan Pasar Cepogo ini menggunakan rangka baja pada bangunan utama dan rangka kayu pada bangunan pasar hewan dan penunjang.

Perencanaan material pada Redesain Pasar Cepogo menyesuaikan dengan tuntutan tampilan bangunan di sekitarnya. Material yang diterapkan adalah material yang kontekstual dan fungsional. Material kontekstual adalah material alami yang berasal dari daerah di sekitarnya. Material fungsional adalah material yang menyesuaikan dengan fungsinya untuk menunjang kegiatan dalam pasar.

1. Material Pengisi Dinding

Material pengisi dinding pada Pasar Cepogo ini direncanakan menggunakan material lokal untuk mencitrakan bangunan pasar yang kontekstual dengan lingkungan sekitarnya yaitu batu bata. Selain itu digunakan pula elemen batu alam sebagai pelapis dinding dan elemen dekoratif pada kolom.

2. Material Atap

Pada Pasar Cepogo ini direncanakan menggunakan material penutup atap berupa genteng sesuai dengan bangunan di sekitarnya. Selain itu juga digunakan atap transparan pada bagian void bangunan sebagai penyaluran pencahayaan alami ke dalam bangunan sebagai pemanfaatan kondisi iklim setempat.

3. Material Penutup Lantai

Material penutup lantai yang digunakan pada Redesain Pasar Cepogo ini adalah material keramik. Pemilihan material ini didasarkan pada standar dan persyaratan pasar tradisional. Selain itu, material ini mudah dibersihkan, mudah dalam pemasangan dan perawatan.

\subsection{Analisis Utilitas}

Perencanaan utilitas sangat penting bagi penunjang kenyamanan dan kebersihan pasar. Utilitas yang baik akan mengatasi permasalahan pasar yang kotor dan kumuh. Oleh karena itu, redesain pasar ini memerlukan perencanaan utilitas yang baik terutama utilitas pembuangan limbah yang terdiri atas:

\subsubsection{Air Kotor Bekas Buangan}

Air kotor bekas buangan terdiri atas air kotor dari toilet dan air kotor dari kios/los yang bersifat basah. Air buangan pada los/kios ini disalurkan melalui saluran yang berada di bawah lapak. Air kotor bekas buangan ini akan melalui proses STP (Sewage Treatment Plant) terlebih dahulu, sehingga air yang dibuang ke lingkungan adalah air yang tidak membahayakan. Kemudian air tersebut disalurkan ke sumur resapan dan sisanya dibuang ke sungai yang dekat dengan tapak (lihat Gambar 12).

\subsubsection{Limbah Kotoran dari WC}

Limbah yang mengandung kotoran padat ini akan disalurkan ke septictank (lihat Gambar 12).

\subsubsection{Air Hujan}

Air hujan disalurkan oleh pipa-pipa pembuangan dari atap yang akan ditampung di bak penampungan dan kemudian didaur ulang, setelah melalui filter dialirkan ke tampungan dan kelebihannya akan diresapkan kembali ke dalam tanah.

\subsubsection{Limbah Kotoran Ternak}

Limbah kotoran ternak dialirkan melalui saluran untuk ditampung terlebih dahulu kemudian dapat diolah menjadi pupuk kompos dan kelebihannya akan disalurkan ke septictank (lihat Gambar 12).

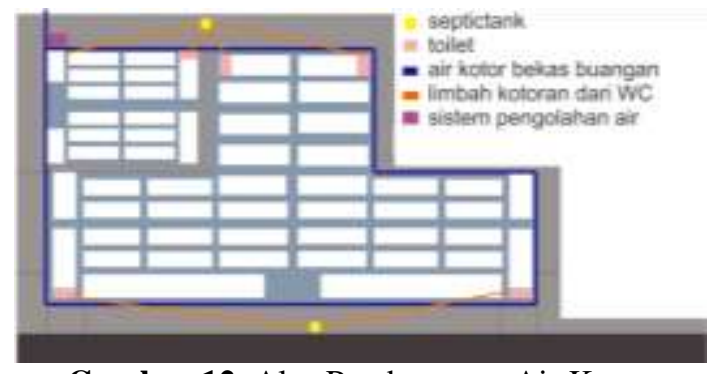

Gambar 12. Alur Pembuangan Air Kotor

\subsubsection{Sampah}

Sumber sampah pada Pasar Cepogo ini berasal dari sampah organik dan anorganik dari kegiatan yang berlangsung di pasar. Untuk pengelolaan sampah tersebut maka direncanakan jaringan pembuangan sampah yang dibedakan jenisnya dan ditempatkan pada beberapa titik. Kemudian sampah yang 
berasal dari bak-bak sampah tersebut dikumpulkan ke tempat pembuangan sampah sementara di dalam tapak, dan selanjutnya akan diangkut oleh truk sampah ke TPA secara berkala (lihat Gambar 13).

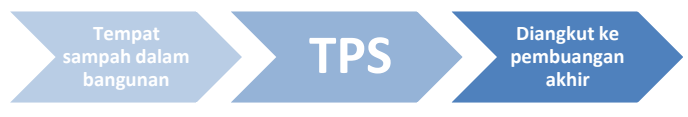

Gambar 13. Alur Pembuangan Sampah pada Tapak

\section{KESIMPULAN}

Redesain Pasar Cepogo Boyolali merupakan perencanaan dan perancangan kembali Pasar Cepogo dengan tujuan mengatasi permasalahan yang ada sekarang ini. Tingkat perubahan yang dilakukan pada redesain ini adalah secara total dengan mempertahankan lokasi, fungsi serta nilai budaya. Pasar cepogo yang direncanakan ini juga merupakan pengembangan pasar sebagai sarana untuk menunjang sektor pariwisata.

Redesain Pasar Cepogo yang direncanakan ini diharapkan tidak mengubah kekhasan dan budayanya sebagai pasar tradisional. Oleh karena itu, pada perancangan ini menggunakan metode desain Arsitektur Kontekstual. Dengan pendekatan ini diharapkan baik perencanaan fisik maupun non fisik dapat selaras dengan lingkungan sekitarnya. Metode Arsitektur Kontekstual ini diterapkan melalui pendekatan fisik lingkungan, iklim, budaya, dan arsitektur lokal. Melalui pendekatan tersebut didapatkan konsep perancangan sebagai berikut (lihat Tabel 2).

Tabel 2. Konsep Desain

\begin{tabular}{|l|l|}
\hline Pendekatan & \multicolumn{1}{|c|}{ Hasil } \\
\hline Fisik & - Pola pencapaian tapak yang \\
dingkungan & disesuaikan dengan kondisi \\
& di sekitar tapak dan \\
& kebutuhan pengguna (lihat \\
& Gambar 1). \\
& - Hasil pemintakatan yang \\
& disesuaikan dengan kondisi \\
& eksisting tapak dan \\
& organisasi ruang (lihat \\
& Gambar 8). \\
& - Penerapan material alam. \\
\hline Iklim & - Pemanfaatan kondisi iklim \\
& sebagai potensi untuk \\
\hline
\end{tabular}

\begin{tabular}{|l|l|}
\hline \multirow{7}{*}{ Budaya } & $\begin{array}{l}\text { menunjang kenyamanan } \\
\text { ruang melalui respon desain } \\
\text { yang disesuaikan dengan } \\
\text { kondisi iklim setempat. }\end{array}$ \\
\hline & $\begin{array}{l}\text { Peruangan yang sesuai } \\
\text { dengan konteks kegiatan } \\
\text { pada Pasar Cepogo, sehingga } \\
\text { seluruh kegiatan pada pasar } \\
\text { terwadahi dan nuansa khas } \\
\text { pasar tradisional tetap terjaga } \\
\text { (lihat Tabel 1). }\end{array}$ \\
\hline Arsitektur & - Bentuk massa yang \\
lokal & menyesuaikan kondisi \\
& eksisting tapak dan konteks \\
& terhadap bangunan sekitar \\
& serta bangunan bersejarah \\
& (lihat Gambar 9). \\
& - Tampilan bangunan yang \\
& menyesuaikan tampilan \\
& bangunan sekitar dengan \\
& menerapkan elemen \\
& Arsitektur Jawa dan elemen \\
& candi (lihat Gambar 10 dan \\
& 11) \\
& - Struktur dan material yang \\
& konteks dengan bangunan \\
& sekitar dan didukung struktur \\
lain yang disesuaikan dengan & aspek fungsi. \\
\hline &
\end{tabular}

\section{REFERENSI}

Brolin, Brent C. 1980. Architecture in Context: Fitting New Buildings with Old. New York: Van Nostrand Reinhold.

Pemerintahan Daerah Kabupaten Boyolali. 2014. Peraturan Daerah Kabupaten Boyolali Nomor 2 Tahun 2014 tentang Pengelolaan dan Pemberdayaan Pasar Tradisional. Boyolali: Pemerintahan Daerah Kabupaten Boyolali.

Widati, Titiani. 2015. Pendekatan Kontekstual dalam Arsitektur Frank Lloyd Wright. Jurnal Persopektif Arsitektur. Vol 11, No. 1, https://jurnalperspektifarsitektur. com/vol-10-no-01-2015/pendekatankontekstual-dalam-arsitektur-franklloyd-wright (Diakses pada 18 Juli 2016 pukul 23.00 WIB). 